\title{
BEGONIA ROBII, A NEW SPECIES OF BEGONIA FROM LIMA PULUH KOTA, WEST SUMATRA
}

Received June 12, 2021; accepted June 26, 2021

\section{WISNU H. ARDI}

Research Center for Plant Conservation and Botanic Gardens-LIPI, Jln. Ir. H. Juanda No. 13, Bogor 16612, Indonesia.

Email: wisnu.handoyo.ardi@lipi.go.id

\section{DEDEN GIRMANSYAH}

Herbarium Bogoriense, Botany Division, Research Center for Biology-LIPI, Cibinong Science Center, Jn. Raya Jakarta-Bogor Km. 46, Cibinong 16911, Bogor, Indonesia.

Email:deden_bo@yahoo.com

\section{MARK HUGHES}

Royal Botanic Garden Edinburgh, 20 A Inverleith Row, Edinburgh EH3 5LR, UK. Email:Mhughes@rbge.org.uk

\author{
ABSTRACT \\ ARDI, W. H., GIRMANSYAH, D. \& HUGHES, M. 2021. Begonia robii, a new species of Begonia from Lima Puluh \\ Kota, West Sumatra. Reinwardtia 20(1): 37-41. - A new species of Begonia sect. Jackia (Begoniaceae), B. robii \\ Ardi \& Girm., is described from West Sumatra and is a limestone karst endemic in the Tanah Datar dan Lima Puluh \\ Kota Regency. Its provisional IUCN threatened category is considered to be Endangered.
}

Key words: Endemic, limestone, Jackia.

\section{ABSTRAK}

ARDI, W. H., GIRMANSYAH, D. \& HUGHES, M. 2021. Begonia robii, jenis baru Begonia dari Lima Puluh Kota, Sumatra Barat. Reinwardtia 20(1): 37-41. - Jenis baru Begonia seksi Jackia (Begoniaceae) dipertelakan dari Sumatra Barat, dan merupakan jenis endemik bebatuan kapur di Kabupaten Tanah Datar dan Lima Pulu Kota. Evaluasi status konservasi berdasarkan IUCN untuk Begonia robii adalah terancam.

Kata kunci: Endemik, batu kapur, Jackia.

\section{INTRODUCTION}

Begonia studies in Sumatra have recently increased the number of species known from the island to 67 (Hughes et al., 2009; Girmansyah et al., 2019; Girmansyah et al., 2020). The diversity is dominated by Begonia sect. Jackia M.Hughes (Moonlight et al., 2018), which has 25 species native to Sumatra. One species is also found in Peninsular Malaysia, Begonia yenyeniae J.P.C.Tan (Tan et al., 2018), while the 24 others are endemic to Sumatra. Begonia sect. Jackia was proposed to accomodate the rhizomatous species from Malesia which formerly belonged to $B$. sect. Reichenheimia. Based on molecular analysis, the rhizomatous species form a clade that is distant both geographically and phylogene tically from $B$. thwaitesii Hook. (Hooker, 1853), type species of $B$. sect. Reichenheimia from Sri Lanka (Moonlight et al., 2018). The other sections found in Sumatra are $B$. sect. Petermannia (Klotzsch) A.DC. (de
Candolle, 1859) with 15 spp., B. sect. Platycentrum (Klotzsch) A.DC. with 13 spp., $B$. sect. Bracteibegonia A.DC. with 13 spp. and $B$. sect. Parvibegonia A.DC with only one species (Hughes et al., 2015).

Here we describe Begonia robii Ardi \& Girm. as a new species from Sumatra in B. sect. Jackia. All available Begonia material in ANDA, BO, E, K, L and SING has been consulted, and therefore it must be assumed, at least until more intensive collecting reveals otherwise, that this species has a restricted distribution and is endemic to West Sumatra.

\section{Species description}

Begonia robii Ardi \& Girm. sp. nov. § Jackia. Figs. $1 \& 2$.

- TYPE: Cultivated at Bogor Botanic Gardens, from material collected in the wild (INDONESIA, Sumatra, West Sumatra, Lima Puluh Kota Regen- 


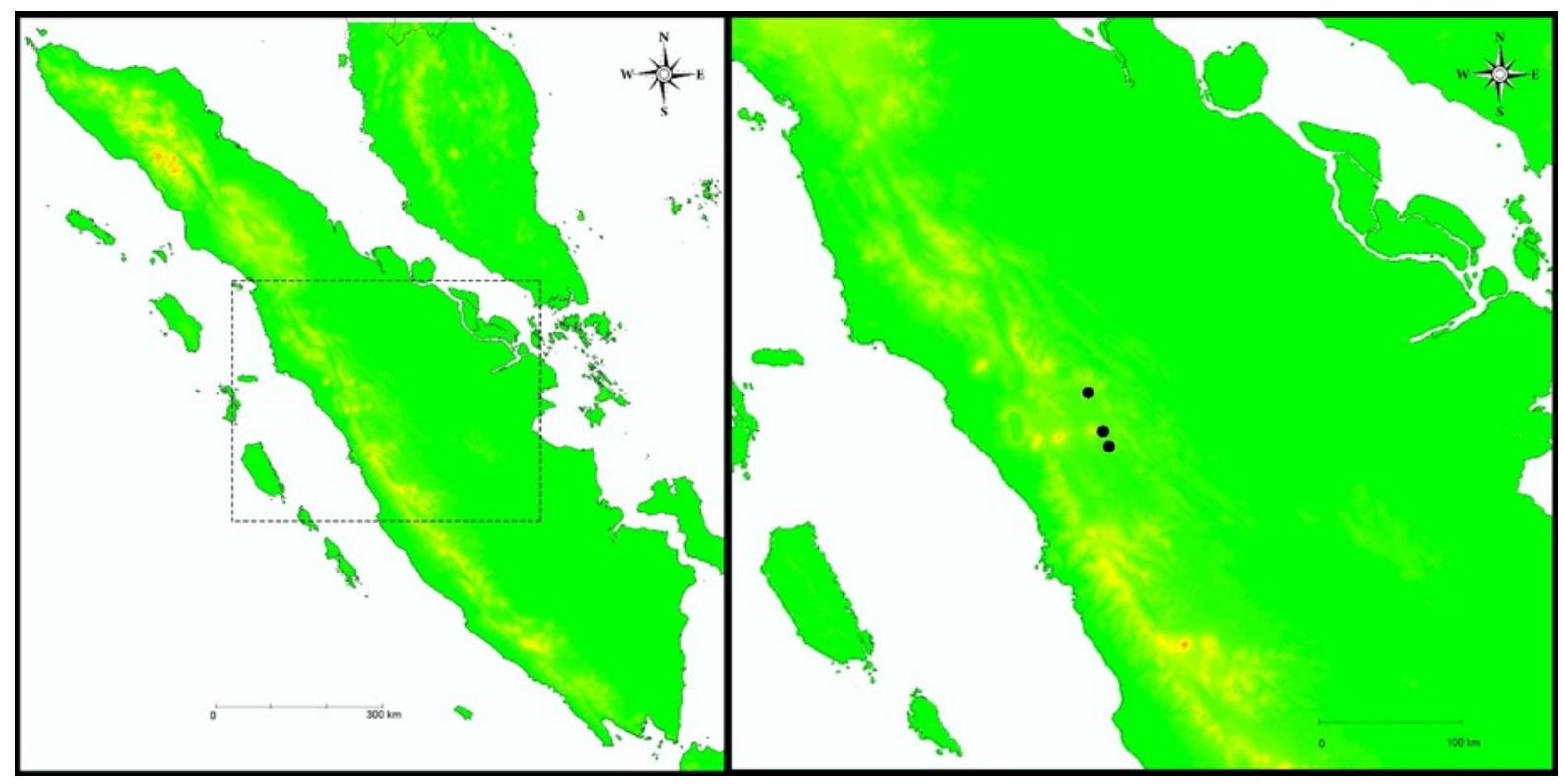

Fig. 1. Distribution of Begonia robii Ardi \& Girm. Collection sites information was georeferenced using Geonames geographical database at http://www.geonames.org

cy, 31 March 2021), Wisnu Handoyo Ardi WI 761 (Holotype BO, isotype E).

A limestone adapted species closely related to Begonia droopiae Ardi (Ardi \& Hughes, 2010), in terms of its habit and variegated leaves, however it can be easily distinguished by its rounded leaf apex which have pale green blotches between the veins (not acuminate at the apex and green on the veins only), outer male flower tepals which are elliptic to obovate with an acute to rounded apex (vs. elliptic to suborbicular with a rounded apex), female flowers with two or three tepals, outer tepals $4-12 \times 7-8.5 \mathrm{~mm}$, elliptic (vs. female flower with three tepals, outer tepals 5.5-6 $\times 4.5-$ $6 \mathrm{~mm}$, orbicular to suborbicular), ovary $c a .8 \times 5-$ $6 \mathrm{~mm}$, ovoid to ellipsoid, wings equal to subequal with a truncate to cuneate base, and a cuneate apex (vs. globose to broadly ellipsoid ovary, 6-7 $\times 10-13 \mathrm{~mm}$, wings equal with rounded base and apex).

Perenial monoecious herb, up to $10 \mathrm{~cm}$ tall. Stem rhizomatous, light green with few white spots, sparsely hairy at the joint of stem and petiole, thickened and brown in older stems, rooting at the nodes, diameter 3-5 mm, internodes compressed 3 $-8 \mathrm{~mm}$. Leaves alternate; stipules persistent, ovate, $8-10 \times 7-9 \mathrm{~mm}$, pale green, asymmetric, midrib abaxially prominent, hairy along the midrib to the apex extension, apex narrowed and extended up to $2 \mathrm{~cm}$ long; petioles 3-9.5 cm long, reddish brown, terete, with long white pilose hairs, up to $4 \mathrm{~mm}$ long; lamina basifixed, broadly ovate, 4-7 × 6-9 cm, asymmetric, reniform, margin crenate, ciliate with recurved stiff teeth at the end of the veins, base cordate, rarely overlapped, apex mostly rounded, rarely shortly acute, adaxially light green on the veins and the leaf base, dark purple patches between the veins and light green blotches, glabrous, bullate, abaxially paler, sparsely hairs along the veins; venation palmate, primary veins 6-7, actinodromous, secondary craspedrodomous. Inflorescences bisexual, axillary, protandrous, cymes branching once dichasially at the base and at the two lateral branches branching monochasially, with up to 4 male flowers and one female at the apex, peduncle $7-13 \mathrm{~cm}$ long, pale green, sparsely hairy; bracts persistent, elliptic, $c a$. $3 \times 2 \mathrm{~mm}$, margin fringed, bracteoles minute, hairlike. Male flowers: pedicels $12-22 \mathrm{~mm}$ long, white, glabrous to sparsely hairy; tepals 4, unequal, 2 outer tepals elliptic to obovate, $c a .8-13$ $\times 8-10 \mathrm{~mm}$, margin entire, apex acute to rounded, white tinged pink, abaxially surface glabrescent; 2 inner tepals spatulate, 5-12 × 3-4.5 mm, margin entire, apex rounded; androecium globose, yellow; stamens 46-50, outer anthers subsessile, inner anthers on filaments about the same length as the anther, anthers $0.50 \mathrm{~mm}$ long, obtriangular, apex retuse, dehiscing through lateral slits about half the length of the anther. Female flowers: pedicel 8-18 


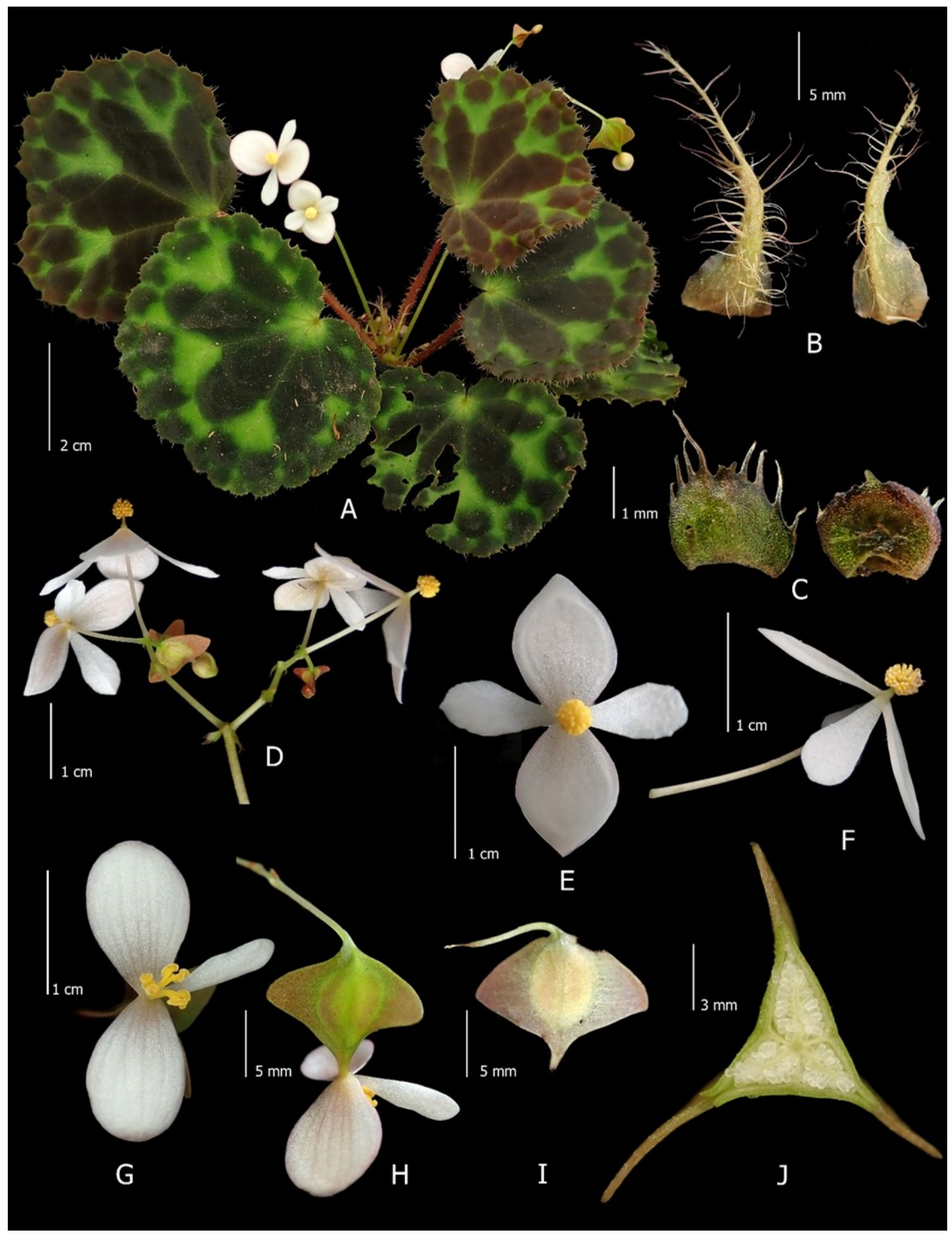

Fig. 2. Begonia robii Ardi \& Girm. A. Plant habit. B. Stipules. C. Bracts. D. Inflorescence. E. Male flower, front view. F. Male flower, side view. G. Female flower, front view. H. Female flower, side view. I. Fruit. J. Ovary, cross section of middle part. From Wisnu Ardi WI 761. Photos by W.H. Ardi. 
Table 1. Morphological characters comparions of Begonia robii, B. nurii and B. yenyeniae.

\begin{tabular}{|c|c|c|c|}
\hline \multirow{2}{*}{ Characters } & \multicolumn{3}{|c|}{ Species } \\
\hline & B. robii & B. nurii & B. yenyeniae \\
\hline Stipule & $\begin{array}{l}\text { Ovate, } 8-10 \times 7-9 \mathrm{~mm} \text {, } \\
\text { pale green, apex } \\
\text { narrowed and extended } \\
\text { up to } 2 \mathrm{~cm} \text { long, hairy }\end{array}$ & $\begin{array}{l}\text { Narrowly triangular 5- } \\
10 \times 3-4 \mathrm{~mm} \text {, red, apex } \\
\text { narrowed filiform } \\
\text { extended }<1 \mathrm{~cm}\end{array}$ & $\begin{array}{l}\text { Narrowly triangular 9- } \\
12 \times 3-4 \mathrm{~mm} \text {, pale } \\
\text { yellowish green, apex } \\
\text { narrowed filiform } \\
\text { extended }<1 \mathrm{~cm}\end{array}$ \\
\hline Lamina & $\begin{array}{l}\text { Broadly ovate, } 4-7 \times 6- \\
9 \mathrm{~cm} \text {, reniform }\end{array}$ & $\begin{array}{l}\text { Suborbicular to orbicu- } \\
\text { lar, }(2-) 4(-7) \times(3-) 4-6 \\
(-11) \mathrm{cm}\end{array}$ & $\begin{array}{l}\text { Orbicular, } 8-15 \times 9.5- \\
13.5 \mathrm{~cm} \text {, reniform }\end{array}$ \\
\hline \multicolumn{4}{|l|}{ Male flowers } \\
\hline Pedicels & $12-22 \mathrm{~mm}$ & $3-7 \mathrm{~mm}$ & $6-9 \mathrm{~mm}$ \\
\hline Male outer tepals & $\begin{array}{l}c a .8-13 \times 8-10 \mathrm{~mm} \text {, } \\
\text { elliptic to obovate, with } \\
\text { acute to rounded apex }\end{array}$ & $\begin{array}{l}4-7 \times 4-5 \mathrm{~mm} \text {, broadly } \\
\text { ovate to suborbicular } \\
\text { with rounded apex }\end{array}$ & $\begin{array}{l}5-7 \times 6 \mathrm{~mm} \text {, suborbicu- } \\
\text { lar with rounded apex }\end{array}$ \\
\hline Male inner tepals & $\begin{array}{l}\text { Two, } 5-12 \times 3-4.5 \mathrm{~mm} \text {, } \\
\text { spatulate, apex rounded }\end{array}$ & $\begin{array}{l}\text { Two, narrowly ovate, } 3- \\
4.5 \times 1-2.5 \mathrm{~mm} \text {, apex } \\
\text { rounded }\end{array}$ & $\begin{array}{l}\text { Two, ca. } 5 \times 3 \mathrm{~mm} \text {, ob- } \\
\text { ovate, apex rounded or } \\
\text { sometime retuse }\end{array}$ \\
\hline \multicolumn{4}{|l|}{ Female flower } \\
\hline Pedicels & $8-18 \mathrm{~mm}$ & $9-15 \mathrm{~mm}$ & 6-9 mm \\
\hline Tepal number & $2-3$ & 2 & 3 \\
\hline Outer tepals & $\begin{array}{l}4-12 \times 7-8.5 \mathrm{~mm} \text {, ellip- } \\
\text { tic, }\end{array}$ & $\begin{array}{l}4-6 \times 3-5 \mathrm{~mm} \text {, broadly } \\
\text { ovate to suborbicular }\end{array}$ & $\begin{array}{l}\text { ca. } 2.8-1.9 \mathrm{~mm} \text {, obo- } \\
\text { vate }\end{array}$ \\
\hline $\begin{array}{l}\text { Ovary (shape and } \\
\text { size) }\end{array}$ & Ovoid to ellipsoid & Ellipsoid & Ellipsoid \\
\hline Wings & $\begin{array}{l}\text { Equal to subequal, } \\
\text { truncate to cuneate at } \\
\text { base, cuneate at the apex }\end{array}$ & $\begin{array}{l}\text { Equal, truncate at base, } \\
\text { cuneate at the apex }\end{array}$ & $\begin{array}{l}\text { Equal, rounded at base, } \\
\text { cuneate to subtruncate at } \\
\text { the base }\end{array}$ \\
\hline \multicolumn{4}{|l|}{ Fruit } \\
\hline Pedicels & $10-20 \mathrm{~mm}$ & $6-10 \mathrm{~mm}$ & ca. $5.5 \mathrm{~mm}$ \\
\hline
\end{tabular}

$\mathrm{mm}$ long, pale green, glabrous; tepals 2-3, unequal, white or white tinged with pink, 2 outer tepals elliptic, 4-12 $\times 7-8.5 \mathrm{~mm}$, margin entire, apex rounded, inner tepal(s) narrowly obovate, 4 $5 \times 1-2 \mathrm{~mm}$ margin entire, apex rounded; ovary (excluding wings) ovoid to ellipsoid, $c a .8 \times 5-6$ $\mathrm{mm}$, reddish, glabrous, locules 3 , placentation axile, placentae entire, total size including the wings $c a .12 \times 11 \mathrm{~mm}$, capsule three locular, placentae entire; wings 3, equal to subequal, base truncate to cuneate, apex cuneate, widest point at the middle part up to $c a .6 \mathrm{~mm}$ long; stigmas 3 , yellow, Y-shaped, ca. $4 \mathrm{~mm}$ long, surface once spirally twisted. Fruit: pendent on a thin 10-20 $\mathrm{mm}$ long pedicels, recurved, seed bearing part ovoid to ellipsoid, $c a .8 .5 \times 6.5 \mathrm{~mm}$, tip beaked, wings shape as for ovary, widest point up to $6 \mathrm{~mm}$ long (middle part). Seeds unknown.

Distribution. Sumatra, endemic to West Sumatra, Lima Puluh Kota and Tanah Datar Regencies (Harau valley, Lintau Buo and Halaban). Fig. 1.

Etymology. The epithet is after the collector, Robi Satria. 
Habitat. Limestone karst or sandstone forest, growing on vertical limestone cliffs in the shade.

\section{Provisional IUCN conservation assessment.} Endangered (EN B1ab(iii), EN B2ab(iii). Based on reports from the collector, Begonia robii is known from three localities of lowland limestone karst or sandstone. One of them is in a protected area, the Harau Valley Forest Reserve, which had small populations, however the habitat was burnt in 2019 and destroyed the populations. The Halaban population is also threatened by road development. The two other localities in Halaban and Lintau Buo, which are not legally protected areas. Although its quite abundant in Lintau, the species threatened by species trade, sold as ornamental plant. Based on georeferences and using GeoCat (Bachman et al., 2011) The extence of occurrence was estimated at $\pm 5000 \mathrm{~km}^{2}$ and area of occupancy $\left(12 \mathrm{~km}^{2}\right)$, in combination with observed threats and on going reduction of its habitat, we asses this species as Endangered.

Notes. Begonia robii is most closely allied with $B$. droopiae as discussed in the diagnosis. There are a few other species with similar habit and leave shape, such as Begonia nurii Irmsch. (Irmscher, 1929) and Begonia yenyeniae J.P.C.Tan, however $B$. robii can be differentiated from these two species by several combinations of characters (see Table 1).

\section{ACKNOWLEDGEMENTS}

We are grateful to Robi Satria who kindly provided the valuable samples. The curators of herbaria ANDA, BO, E, K, L and SING are thanked for facilitating access to specimens.

\section{REFERENCES}

ARDI, W. H. \& HUGHES, M. 2010. Begonia droopiae Ardi (Begoniaceae), a new species of Begonia from West Sumatra. Gard. Bull. Singapore 62(1): 19-24.

BACHMAN, S., MOAT, J., HILL, A. W., TORRE, J. de la. \& SCOTT, B. 2011. Supporting Red List threat assessments with GeoCat: geo- spatial conservation assessment tool. Zookeys 150: 117-126.

DE CANDOLLE, A. L. P. P. 1859. Mémoire sur la famille des Bégoniacées. Ann. Des. Sci. Nat. Bot. sér 4 11: 93-149.

GIRMANSYAH, D., SULISTIJORINI, RUGAYAH, T. \& CHIKMAWATI, T. 2020. A key to Begonia section Bracteibegonia from Sumatra with one new species and rediscovery of Begonia fasciculata Jack. Phytotaxa 475(4): 289-295.

GIRMANSYAH, D., SUSILA \& HUGHES, M. 2019. A revision of Begonia sect. Petermannia on Sumatra, Indonesia. Phytotaxa 407(1): 79100.

HOOKER, J. D. 1853. Begonia thwaitesii. $\mathrm{Mr}$ Thwaites' Begonia. Curtis' Bot. Mag. 79: t. 4689.

HUGHES, M., GIRMANSYAH, D., ARDI, W. H. $\&$ NURAINAS. 2009. Seven new species of Begonia from Sumatra. Gard. Bull. Singapore 61(1): 29-44.

HUGHES, M., MOONLIGHT, P.W., JARA, A. \& PULLAN, M. 2015. Begonia Resource Centre. Available at: http://padme.rbge.org.uk/begonia (Accessed 28 October 2019).

IRMSCHER, E. 1929. Die Begoniaceen der Malaiischen Halbinsel. Mitt. Inst. Allg. Bot. Hambg. 8: 87-160.

MOONLIGHT, P. W., ARDI, W. H., PADILLA, L. A., CHUNG, K. F., FULLER, D., GIRMANSYAH, D., HOLLANDS, R., MAHARDIKA, A., JARA-MUÑOZ, A., KIEW, R., MARASINGHE, L. D. K., LEONG, W. C., LIU, Y., O'CONNOR, M., PENG, C. -I, PÉREZ, Á. J., PHUTTHAI, T., PULLAN, M., RAJBHANDARY, S., REYNEL, C., RUBITE, R. R., JULIA, S., SCHERBERICH, D., SHUI, Y. -M., TEBBITT, M. C., THOMAS, D. C., ZAINI, N. H. \& HUGHES, M. 2018. Dividing and conquering the fastest growing genus: Towards a natural sectional classification of the mega-diverse genus Begonia (Begoniaceae). Taxon 67(2): 267-323.

TAN, J. P. -C., TAM, S. M. \& KIEW, R. 2018. Begonia yenyeniae (Begoniaceae), a new species from Endau Rompin National Park, Johor, Malaysia. PhytoKeys 110: 23-37. 